\title{
UPAYA MENINGKATKAN KEDISIPLINAN MENGAJAR GURU MELALUI SUPERVISI AKADEMIK DENGAN TEKNIK INDIVIDUAL DI SD NEGERI CANDIREJO 01 \\ TAHUN 2014 - 2015
}

\author{
Kunthi Arifah \\ kunthiarifah@gmail.com \\ SD Negeri Candirejo 01 - Tuntang, Kabupaten Semarang
}

\begin{abstract}
ABSTRAK
Penelitian ini bertujuan meningkatkan kedisiplinan mengajar guru dalam melaksanakan tugas yang bertujuan untuk meningkatkan kualitas hasil pembelajaran. Strategi yang digunakan adalah penelitian tindakan sekolah yang dilakukan dalam 2 siklus, yang setiap siklusnya meliputi kegiatan rencana tindakan, pelaksanaan tindakan, pemantauan dan evaluasi, serta analisis dan refleksi. Waktu penelitian 4 bulan dimulai dari bulan Januari 2015 sampai dengan bulan April 2015. Adapun subyek penelitian adalah guru SD Negeri Candirejo 01, sedang obyeknya adalah penyusunan perangkat pembelajaran, pelaksanaan kegiatan pembelajaran, dan evaluasi. Teknik pengumpulan data dalam penelitian ini adalah teknik observasi, dokumentasi dan wawancara. Analisis data dilakukan dengan menggunakan analisis deskriptif komparatif dengan membandingkan data kondsi awal dibandingkan data siklus I dan juga dibandingkan dengan data yang diperoleh pada siklus II setelah dilakukan deskriptif komparatif dilanjutkan refleksi. Hasil penelitian yang diperoleh menunjukkan bahwa pelaksanaan supervisi akademik dengan teknik individual dapat meningkatkan kedisiplinan mengajar guru SD Negeri Candirejo 01 yang meliputi kedisiplinan dalam menyusun perencanaan pembelajaran, kedisiplinan melaksanakan kegiatan pembelajaran, kedisiplinan melaksanakan evaluasi di akhir pembelajaran.
\end{abstract}

Kata kunci: Kedisiplinan Mengajar Guru, Supervisi Akademik Teknik Individual

\section{PENDAHULUAN}

Guru merupakan komponen vital, penggerak utama sebagai faktor penentu kesuksesan dari sistem pendidikan dan pengajaran yang akhirnya akan mempengaruhi produktifitas sekolah. Secara umum kualitas pendidikan formal yang tercermin dari lulusannya sangat dipengaruhi oleh kualitas siswa, proses belajar mengajar, dan kedisiplinan mengajar guru. Haryadi (2005) menyatakan bahwa kualitas pendidikan dipengaruhi oleh kualitas tenaga pengajar, sistem belajar mengajar, sarana dan prasarana, lokasi, serta dministrasi dan birokrasi. Oleh karena itu salah satu upaya yang harus dilaksanakan untuk meningkatkan kualitas sekolah 
adalah melalui peningkatan kedisiplinan mengajar guru. Hal ini sejalan dengan pendapat Kusumastuti (2001), yang menyatakan bahwa pengembangan mutu pendidikan dapat ditempuh melalui pengembangan mutu para pendidiknya.

Upaya pengembangan mutu pendidik diharapkan ada peningkatan mutu pendidikan yang tercermin melalui lulusan. Memang ada banyak faktor yang mempengaruhi nilai kelulusan siswa, antara lain adalah kemampuan dan kondisi siswa, tingkat kesulitan soal ujian, dan kinerja lembaga. Salah satu kinerja lembaga yang sangat berpengaruh terhadap kelulusan siswa adalah kedisiplinan mengajar guru yang optimal. Ketidakoptimalan kedisiplinan mengajar guru sangat dimungkinkan karena kurang optimalnya supervisi akademik yang dilakukan kepala sekolah. Siswoyo (2006) mengatakan, agar kedisiplinan mengajar guru meningkat sangat dibutuhkan pemimpin yang mampu memberdayakan karyawan utamanya adalah guru. Guru merupakan ujung tombak keberhasilan pendidikan. Bila mutu pendidikan tidak baik maka guru yang menjadi sasaran pertama. Bagaimana gurunya? Ini menunjukkan bahwa masyarakat menyerahkan sepenuhnya keberhasilan pendidikan generasi muda kepada guru.

Bafadal (2006) mengatakan bahwa tugas pokok kepala sekolah adalah mengelola penyelenggaraan kegiatan pendidikan dan pembelajaran di sekolah. Seterusnya dikatakan secara lebih operasional bahwa tugas pokok kepala sekolah mencakup kegiatan menggali dan mendayagunakan seluruh sumber daya sekolah secara terpadu dalam rangka pencapaian tujuan sekolah secara efektif dan efisien. Mulyasa (2004) mengatakan, kepala sekolah memiliki peran kuat dalam mengkoordinasikan, menggerakkan dan menyerasikan semua sumber daya pendidikan yang tersedia di sekolah. Kepala sekolah merupakan salah satu faktor pendorong sekolah untuk dapat mewujudkan visi, misi, tujuan, dan sasaran sekolahnya melalui program-program yang dilaksanakan secara terencana dan bertahap. Berdasar pendapat di atas, jelas bahwa kepala sekolah memegang peranan penting. Oleh karena itu supervisi akademik dari kepala sekolah yang optimal akan mendorong peningkatan kedisiplinan mengajar guru. Sebaliknya supervisi akademik yang kurang optimal akan melemahkan kedisiplinan mengajar guru.

Supervisi akademik adalah serangkaian kegiatan membantu guru mengembangkan kemampuannya mengelola proses pembelajaran untuk mencapai tujuan pembelajaran (Daresh, 1989, Glickman, et al.2007). Melihat begitu luas dan kompleksnya tugas dan fungsi dari suatu sekolah, maka dalam melaksanakan tugas pokok dan fungsi tersebut sangat membutuhkan guru yang mempunyai semangat kerja tinggi. Salah satu indikator yang menunjukkan semangat kerja tinggi adalah kedisiplinan mengajar guru.

Pertimbangan penulis mengadakan penelitian ini, meskipun pada tahun pelajaran 2013-2014 telah dilakukan penelitian tentang pembinaan akademik pada guru-guru untuk meningkatkan minat dan kemampuan menyusun RPP, dan hasilnya 
menunjukkan ada peningkatan minat dan kemampuan guru-guru SD Candirejo 01 dalam menyusun RPP, namun setahun kemudian kedisiplinan guru dalam mengajar kembali rendah, hal ini ditandai dengan kedisiplinan guru dalam menyusun perencanaan pembelajaran, melaksanakan pembelajaran, dan melaksanakan evaluasi pada kategori rendah. Untuk itu diperlukan optimalisasi supervisi akademik dengan teknik individual dengan harapan bisa meningkatkan kedisiplinan mengajar guru tersebut. Hal inilah yang membuat penulis melakukan penelitian tindakan sekolah tetang upaya meningkatkan kedisiplinan mengajar guru melalui supervisi akademik dengan teknik individual.

Berdasarkan latar belakang di atas, rumusan masalah yang penulis ajukan adalah: Apakah melalui supervisi akademik dengan teknik individual dapat meningkatkan kedisiplinan mengajar guru SD Negeri Candirejo 01?. Seturut dengan permasalahan tersebut, maka tujuan penelitian ini adalah untuk mengetahui apakah melalui supervisi akademik dengan teknik individual dapat meningkatkan kedisiplinan mengajar guru SD Candirejo 01.

\section{KAJIAN PUSTAKA}

\section{Kedisiplinan Mengajar Guru}

Menurut Halsey (dalam Tu'u, 2004) istilah disiplin dalam Bahasa Inggris berasal dari kata discipline yang berarti tertib, taat, mengendalikan tingkah laku, penguasaan diri, dan kendali diri. Sedangkan menurut Rachman (1999) disiplin merupakan upaya mengendalikan diri dan sikap mental individu atau masyarakat dalam mengembangkan kepatuhan dan ketaatan terhadap peraturan dan tata tertib berdasarkan dorongan dan kesadaran yang muncul dari dalam hatinya. Slameto (1988) juga memberikan pengertian bahwa disiplin adalah suatu sikap yang menunjukkan kesediaan untuk menepati atau mematuhi dan mendukung ketentuan tata tertib, peraturan, nilai, dan kaidah-kaidah yang berlaku pada lingkungan tertentu. Disebutkan juga bahwa dalam disiplin terkandung asas taat yaitu kemampuan untuk bersikap dan bertindak secara konsisten berdasar pada suatu nilai tertentu.

Gunarsa (1987) menyebutkan bahwa kedisiplinan berasal dari kata disiplin yang berarti sikap mental yang mengandung kerelaan untuk mematuhi semua ketentuan, peraturan, dan norma yang berlaku dalam menunaikan tugas dan kewajiban. Hasibuan (2000) mengatakan bahwa kedisiplinan adalah kesadaran dan kesediaan seseorang menaati semua peraturan yang berlaku. Sedangkan Damayanti dkk (2002) mengatakan bahwa kedisiplinan mengajar guru berkaitan dengan kinerja guru. Kualitas guru yang dibutuhkan dalam era pembangunan adalah mereka yang mampu dan siap berperan secara profesional dalam dua lingkungan besar yaitu lingkungan sekolah dan lingkungan masyarakat. Menurut Damayanti (2002), guru 
yang profesional adalah guru yang dapat menunjukkan kinerja mengajar yang tinggi dalam tugasnya dan dapat berintegrasi dengan warga sekolah (sesama guru, siswa, staf administrasi), dan masyarakat di luar lingkungan sekolah. Untuk menghasilkan guru yang memiliki disiplin tinggi dalam kinerjanya ada empat kompetensi yang mesti dimiliki guru, yaitu kompetensi pedagogik, kompetensi kepribadian, kompetensi sosial, dan kompetensi profesional yang didapat dari pendidikan profesi (UU Nomor 14 tahun 2005 pasal 10 ayat 1).

Aqib (2002) mengatakan bahwa guru adalah faktor penentu bagi keberhasilan pendidikan di sekolah karena guru merupakan salah satu sumber belajar bagi siswa. Guru merupakan komponen yang berpengaruh dalam peningkatan mutu pendidikan di sekolah artinya kemampuan atau kompetensi profesional guru sangat menentukan kualitas / mutu pendidikan.

Sugiyono dkk (2004) mengatakan bahwa mutu pendidikan belum dapat memenuhi kualitas yang baik yang diduga penyebabnya antara lain adalah 1) kurangnya kedisiplinan guru dalam melaksanakan tugas, 2) mutu guru menurun, 3) kurangnya penghargaan terhadap guru. Penghargaan ini sangat penting yang salah satunya untuk memotivasi kediplinan kerja guru. Penghargaan dapat berupa pujian, hadiah, surat penghargaan, dan lain sebagainya.

Sudiyono (2000) menyebutkan bahwa kedisiplinan guru adalah prestasi yang diperlihatkan guru dalam melaksanakan tugas pokok dalam mengajar, mendidik, dan melatih. Dalam mengajar yang diperlihatkan guru adalah menyampaikan materi ajar (sikap, pengetahuan, dan keterampilan) kepada siswa. Hal ini disebabkan guru mempunyai kemampuan merencanakan, melaksanakan, dan mengevaluasi proses belajar mengajar dalam suasana interaksi edukatif di sekolah (Sudiyono 2000). Guru yang mempunyai kedisiplinan mengajar yang tinggi adalah guru yang mengutamakan tugasnya (merencanakan, melaksanakan dan mengevaluasi proses belajar mengajar), sehingga secara berkelanjutan akan mewujudkan dan meningkatkan prestasi kerja yang dimanifestasikan dalam bentuk kerja keras, tekun, dan berwawasan ke depan. Berdasarkan Keputusan Mendikbud RI Nomor 025/0/1995 tentang petunjuk teknis ketentuan pelaksanaan jabatan fungsional guru dan angka kredit, unsur utama yang merupakan refleksi mengajar guru diukur dari prestasi yang dicapai atau dilaksanakan oleh guru mulai dari kemampuan merencanakan pembelajaran, kemudian melaksanakan pembelajaran, serta melaksanakan evaluasi.

Dari pendapat Hasibuan, Sudiyono, dan Keputusan Mendikbud RI Nomor 025/0/1995, yang dimaksud dengan kedisiplinan mengajar guru adalah kesadaran dan kesediaan guru dalam melaksanakan tugas pokok dalam mengajar yang meliputi kedisiplinan dalam menyusun perencanaan pembelajaran, kedisiplinan melaksanakan kegiatan pembelajaran, kedisiplinan melaksanakan evaluasi di akhir pembelajaran. 
Upaya Meningkatkan Kedisiplinan Mengajar Guru Melalui Supervisi Akademik dengan

Teknik Individual ..(Kunthi Arifah)

\section{Supervisi Akademik}

Supervisi akademik adalah serangkaian kegiatan membantu guru mengembangkan kemampuannya mengelola proses pembelajaran demi pencapaian tujuan pembelajaran (Glickman, 1981). Supervisi akademik diselenggarakan dengan maksud untuk memonitor kegiatan belajar mengajar di sekolah. Kegiatan memonitor ini bisa dilakukan melalui kunjungan kepala sekolah ke kelas-kelas di saat guru sedang mengajar, percakapan pribadi dengan guru, teman sejawatnya, maupun dengan sebagian murid-muridnya. Supervisi akademik yang baik harus mampu membuat guru semakin kompeten, yaitu guru semakin menguasai kompetensi, baik kompetensi kepribadian, kompetensi pedagogik, kompetensi profesional, dan kompetensi sosial. Oleh karena itu, supervisi akademik harus menyentuh pada pengembangan seluruh kompetensi guru.

Konsep supervisi yang dirumuskan oleh Kimball Wiles (1967) sebagai berikut : "Supervision is assistance in the devolepment of a better teaching learning situation". Supervisi adalah bantuan dalam pengembangan situasi pembelajaran yang lebih baik. Rumusan ini mengisyaratkan bahwa layanan supervisi meliputi keseluruhan situasi belajar mengajar (goal, material, technique, method, teacher, student, an envirovment).

Adam dan Dickey merumuskan supervisi sebagai pelayanan khususnya menyangkut perbaikan proses belajar mengajar. Sedangkan Depdiknas (1994) merumuskan supervisi sebagai berikut : "Pembinaan yang diberikan kepada seluruh staf sekolah agar mereka dapat meningkatkan kemampuan untuk mengembangkan situasi belajar mengajar yang lebih baik". Dengan demikian, supervisi ditujukan kepada penciptaan atau pengembangan situasi belajar mengajar yang lebih baik.

Tujuan supervisi adalah memberikan layanan dan bantuan untuk meningkatkan kualitas mengajar guru di kelas yang pada gilirannya untuk meningkatkan kualitas belajar siswa. Bukan saja memperbaiki kemampuan mengajar tetapi juga mengembangkan potensi kualitas guru (Sahertian, 2000:19). Menurut Sergiovanni (1987) ada tiga tujuan supervisi akademik, yaitu supervisi akademik diselenggarakan dengan maksud membantu guru mengembangkan kemampuan profesionalnnya dalam memahami akademik, kehidupan kelas, mengembangkan keterampilan mengajarnya dan menggunakan kemampuannya melalui teknik-teknik tertentu.

Untuk melaksanakan supervisi akademik secara efektif diperlukan keterampilan konseptual, interpersonal dan teknikal (Glickman, at al.2007). Oleh sebab itu, setiap kepala sekolah harus memiliki keterampilan teknikal berupa kemampuan menerapkan teknik-teknik supervisi yang tepat dalam melaksanakan supervisi akademik. Teknik-teknik supervisi akademik meliputi dua macam, yaitu individual dan kelompok (Gwyn, 1961). Teknik supervisi individual adalah 
pelaksanaan supervisi perseorangan terhadap guru. Salah satu teknik supervisi individual yaitu kunjungan kelas yang dilaksanakan dengan empat tahap, dimulai dari tahap persiapan, tahap pengamatan, tahap akhir kunjungan dan tahap tindak lanjut.

\section{Kerangka pikir}

Salah satu tugas kepala sekolah adalah melaksanakan supervisi akademik. Dan tujuan supervisi adalah memberikan layanan dan bantuan untuk meningkatkan kualitas mengajar guru di kelas yang pada gilirannya untuk meningkatkan kualitas belajar siswa. Bukan saja memperbaiki kemampuan mengajar tetapi juga mengembangkan potensi kualitas guru (Sahertian, 2000:19). Ini berarti dengan supervisi akademik dapat meningkatkan kedisiplinan mengajar guru yang meliputi kedisiplinan dalam menyusun perencanaan pembelajaran, kedisiplinan melaksanakan kegiatan pembelajaran, dan kedisiplinan melaksanakan evaluasi di akhir pembelajaran.

\section{Hipotesis Tindakan}

Berdasarkan kerangka berpikir di atas, maka hipotesis tindakan dalam penelitian ini adalah melalui supervisi akademik dengan teknik individual dapat meningkatkan kedisiplinan mengajar guru SD Negeri Candirejo 01.

\section{METODE PENELITIAN}

Penelitian tindakan sekolah ini dilakukan selama empat bulan dimulai awal bulan Januari sampai dengan akhir bulan April 2015. Subyek penelitiannya adalah guru-guru SD Negeri Candirejo 01 yang berjumlah delapan orang, enam orang guru kelas dan dua orang guru mata pelajaran. Lokasi tempat penulis mengadakan penelitian di SD Negeri Candirejo 01 dengan alamat Jl. Mertokusumo No 32 Candirejo Kecamatan Tuntang. Penelitian tindakan ini direncanakan dalam 2 siklus, yang mana setiap siklus merupakan kegiatan yang meliputi rencana tindakan, pelaksanaan tindakan, pemantauan dan evaluasi, serta analisis data dan refleksi.

Teknik pengumpulan data dalam penelitian ini menggunakan teknik observasi, dokumentasi dan wawancara untuk menilai kedisiplinan dalam menyusun perencanaan pembelajaran yang indikator/aspeknya adalah menyiapkan perangkat pembelajaran, menyiapkan RPP setiap akan mengajar, menyiapkan evaluasi dengan berbagai jenjang pemikiran, menyiapkan rencana evaluasi dengan berbagai bentuk soal, menyiapkan rencana tindak lanjut. Juga untuk menilai kedisiplinan dalam melaksanakan pembelajaran yang indikator/aspeknya antara lain datang tepat waktu, mengakhiri pelajaran tepat waktu, menjelaskan tujuan di awal pembelajaran, menegur siswa yang mengganggu siswa lain, memberikan PR, mengoreksi PR, memotivasi siswa, menggunakan berbagai metode dan model pembelajaran, 
memanfaatkan media/alat peraga, menggunakan bahasa yang komunikatif, mengorganisasikan kegiatan, dan berinteraksi secara komunikatif dengan siswa. Selain itu juga untuk menilai kedisiplinan dalam melaksanakan evaluasi yang indikator/aspeknya meliputi memberi ulangan formatif setelah satu KD selesai, memberi evaluasi di akhir pembelajaran, menentukan soal berdasarkan tingkat kesukaran, memberi hukuman pada siswa yang berbuat curang dalam ulangan, mengembalikan hasil evaluasi siswa tidak lebih dari satu minggu setelah diadakan evaluasi, menyerahkan nilai tepat waktu, memberi penghargaan pada siswa yang berhasil mendapatkan nilai tertinggi, melakukan analisa terhadap hasil evaluasi, memberikan perbaikan pada siswa yang nilai ulangannya belum mencapai kkm, memberikan pengayaan bagi siswa yang nilai ulangannya diatas $\mathrm{kkm}$, memberikan ulangan sumatif, dan memberikan laporan pendidikan pada orang tua siswa.

Analisis data dilakukan dengan menggunakan analisis deskriptif kategoris dan komparatif. Teknik deskriptif kategoris dilakukan untuk mendeskripsikan data kedisiplinan guru dengan kategori amat baik (AB), baik (B), cukup (C), kurang (K) dan sangat kurang (SK). Teknik deskriptif komparatif dilakukan dengan membandingkan data kondsi awal, siklus pertama dan siklus kedua. Setelah dilakukan deskriptif komparatif dilanjutkan refleksi.

\section{HASIL PENELITIAN DAN PEMBAHASAN}

\section{Hasil Penelitian Tindakan}

Penelitian tindakan terhadap kedisiplinan mengajar guru ini dilakukan dengan melakukan supervisi secara individual mulai dari perencanaan dan pelaksanaan kegiatan selama 2 siklus, setiap siklus menggunakan 1 kali supervisi. Setiap kegiatan supervisi memerlukan waktu 2 × 35 menit.

\section{Deskripsi Kondisi Awal}

Data kondisi awal yang diambil melalui dokumentasi, wawancara dan pengamatan adalah sebagai berikut :

Tabel 1

Data Kondisi Awal Kedisiplinan Menyusun Perencanaan Pembelajaran

\begin{tabular}{|c|c|c|c|c|c|c|c|c|c|}
\hline \multirow{2}{*}{ No } & \multirow{2}{*}{ Guru } & \multicolumn{5}{|c|}{ Indikator /aspek } & \multirow{2}{*}{$\begin{array}{l}\text { Total } \\
\text { skor }\end{array}$} & \multirow{2}{*}{$(\%)$} & \multirow{2}{*}{ Kategori } \\
\hline & & 1 & 2 & 3 & 4 & 5 & & & \\
\hline 1 & Set. & 1 & 2 & 2 & 1 & 1 & 9 & 36 & $\mathrm{~K}$ \\
\hline 2 & D.N & 2 & 2 & 1 & 2 & 2 & 9 & 36 & $\mathrm{~K}$ \\
\hline 3 & Ret. & 3 & 2 & 2 & 2 & 2 & 11 & 44 & $\mathrm{C}$ \\
\hline 4 & Mak. & 3 & 2 & 2 & 3 & 2 & 12 & 48 & $\mathrm{C}$ \\
\hline 5 & S. B & 3 & 3 & 2 & 3 & 3 & 14 & 56 & $\mathrm{C}$ \\
\hline 6 & T.U & 3 & 3 & 2 & 2 & 3 & 13 & 52 & $\mathrm{C}$ \\
\hline 7 & D.W & 2 & 1 & 1 & 1 & 2 & 7 & 28 & $\mathrm{~K}$ \\
\hline 8 & M. A & 1 & 1 & 1 & 1 & 1 & 5 & 20 & SK \\
\hline \multicolumn{7}{|c|}{ Rata-rata } & 10 & 40 & $\mathrm{~K}$ \\
\hline
\end{tabular}


Dari data tersebut diambil kesimpulan bahwa rata-rata kedisiplinan guru dalam menyusun perencanaan pembelajaran dalam kondisi kurang.

Tabel 2

Data Kondisi Awal Kedisiplinan Melaksanakan Pembelajaran

\begin{tabular}{|c|l|c|c|c|c|c|c|c|c|c|c|c|c|c|c|c|}
\hline \multirow{2}{*}{ No } & \multirow{2}{*}{ Guru } & \multicolumn{10}{|c|}{$\begin{array}{c}\text { Total } \\
\text { skor }\end{array}$} & \multirow{2}{*}{ (\%) } & \multirow{2}{*}{ Ktgri } \\
\hline & & $\mathbf{1}$ & $\mathbf{2}$ & $\mathbf{3}$ & $\mathbf{4}$ & $\mathbf{5}$ & $\mathbf{6}$ & $\mathbf{7}$ & $\mathbf{8}$ & $\mathbf{9}$ & $\mathbf{1 0}$ & $\mathbf{1 1}$ & $\mathbf{1 2}$ & \\
\hline 1 & Set. & 3 & 2 & 1 & 1 & 2 & 1 & 1 & 1 & 1 & 1 & 1 & 1 & 16 & 26,67 & $\mathrm{~K}$ \\
\hline 2 & D.N & 1 & 1 & 1 & 1 & 1 & 1 & 2 & 2 & 1 & 2 & 2 & 3 & 18 & 30 & $\mathrm{~K}$ \\
\hline 3 & Ret. & 1 & 1 & 3 & 3 & 3 & 2 & 2 & 2 & 2 & 3 & 3 & 3 & 28 & 46,67 & $\mathrm{C}$ \\
\hline 4 & Mak. & 1 & 3 & 3 & 3 & 3 & 3 & 3 & 4 & 3 & 3 & 3 & 3 & 35 & 58,33 & $\mathrm{C}$ \\
\hline 5 & S. B & 4 & 4 & 3 & 3 & 3 & 3 & 3 & 4 & 3 & 3 & 3 & 4 & 40 & 66,67 & B \\
\hline 6 & T.U & 3 & 3 & 3 & 2 & 2 & 2 & 2 & 2 & 2 & 3 & 3 & 3 & 30 & 50 & C \\
\hline 7 & D.W & 1 & 1 & 1 & 1 & 1 & 1 & 1 & 1 & 1 & 1 & 1 & 1 & 12 & 20 & SK \\
\hline 8 & M. A & 1 & 1 & 1 & 1 & 1 & 1 & 1 & 1 & 1 & 1 & 1 & 1 & 12 & 20 & SK \\
\hline \multicolumn{10}{|c|}{ Rata-rata } \\
\hline \multicolumn{10}{|c|}{}
\end{tabular}

Dari tabel tersebut diambil kesimpulan bahwa rata-rata kedisiplinan guru dalam melaksanakan pembelajaran dalam kondisi kurang.

Tabel 3

Data Kondisi Awal Kedisiplinan Melaksanakan Evaluasi

\begin{tabular}{|c|c|c|c|c|c|c|c|c|c|c|c|c|c|c|c|c|}
\hline \multirow{2}{*}{ No } & \multirow{2}{*}{ Guru } & \multicolumn{12}{|c|}{ Indikator/Aspek } & \multirow{2}{*}{$\begin{array}{l}\text { Total } \\
\text { skor }\end{array}$} & \multirow{2}{*}{$(\%)$} & \multirow{2}{*}{ Ktgri } \\
\hline & & 1 & 2 & 3 & 4 & 5 & \begin{tabular}{l|}
6 \\
\end{tabular} & 7 & 8 & 9 & 10 & 11 & 12 & & & \\
\hline 1 & Set. & 2 & 2 & 1 & 1 & 1 & 2 & 2 & 2 & 2 & 2 & 2 & 2 & 21 & 35 & $\mathrm{~K}$ \\
\hline 2 & D.N & 3 & 2 & 2 & 2 & 2 & 2 & 2 & 2 & 2 & 2 & 2 & 2 & 25 & 41,67 & $\mathrm{C}$ \\
\hline 3 & Ret. & 2 & 2 & 2 & 2 & 2 & 2 & 2 & 2 & 2 & 3 & 2 & 3 & 26 & 43,33 & $\mathrm{C}$ \\
\hline 4 & Mak. & 2 & 2 & 2 & 2 & 2 & 2 & 2 & 2 & 1 & 1 & 3 & 3 & 24 & 40 & $\mathrm{~K}$ \\
\hline 5 & S. B & 3 & 4 & 3 & 3 & 3 & 3 & 3 & 3 & 3 & 3 & 4 & 4 & 39 & 65 & B \\
\hline 6 & T.U & 2 & 2 & 3 & 3 & 3 & 3 & 3 & 2 & 2 & 2 & 3 & 3 & 31 & 51,67 & $\mathrm{C}$ \\
\hline 7 & D.W & 1 & 1 & 1 & 1 & 1 & 1 & 1 & 1 & 1 & 1 & 1 & 1 & 12 & 20 & SK \\
\hline 8 & M. A & 1 & 1 & 1 & 1 & 1 & 1 & 1 & 1 & 1 & 1 & 1 & 1 & 12 & 20 & SK \\
\hline & & & & & & ta- & & & & & & & & 23,75 & 39,58 & $\mathrm{~K}$ \\
\hline
\end{tabular}

Dari data tersebut diambil kesimpulan bahwa rata-rata kedisiplinan guru dalam melaksanakan evaluasi dalam kondisi kurang. Dan dari Tabel 1,Tabel 2, dan Tabel 3 terlihat bahwa kedisiplinan mengajar guru dalam kondisi kurang, sehingga sangat perlu diadakan optimalisasi supervisi akademik dengan teknik individual agar kedisiplinan guru dalam mengajar dapat meningkat.

\section{Siklus I}

Siklus 1 dilakukan 1 kali pertemuan untuk setiap guru. Peneliti mengawali siklus dengan melakukan tahap perencanaan tindakan yang mencakup kegiatan : (1) Kepala sekolah menyusun instrumen supervisi, lembar observasi dan 
lembar wawancara, (2) Kepala sekolah mengingatkan kembali kepada guru berkaitan dengan penyusunan silabus, RPP, daftar nilai, dan kelengkapan mengajar melalui pembinaan, (3) Kepala sekolah menyampaikan rencana kegiatan kepada guru dan diberitahukan bahwa penelitian dilakukan pada semua guru yang berjumlah 8 orang, (a) Kepala sekolah mengecek kelengkapan administrasi mengajar, (b) Kepala sekolah melakukan wawancara sebelum melaksanakan supervisi kunjungan kelas untuk menyepakati aspek -aspek yang akan disupervisi.

Selanjutnya kepala sekolah mulai melaksanakan tindakan dengan melaksanakan kegiatan supervisi akademik teknik individual, dengan melakukan kunjungan kelas sesuai dengan jadwal yang telah disepakati. Kunjungan kelas ini dilaksanakan dengan empat tahap, dimulai dari tahap persiapan, tahap pengamatan, tahap akhir kunjungan dan tahap tindak lanjut yaitu melakukan diskusi dengan guru yang disupervisi untuk mengevaluasi penampilan guru pada saat kegiatan pembelajaran. Adapun hasil pengamatan dari kegiatan supervisi akademik dengan teknik individual dengan melakukan supervisi kunjungan kelas, datanya tergambar dalam tabel 4.

Tabel 4

Data Kondisi Akhir Siklus I

Kedisiplinan Menyusun Perencanaan Pembelajaran

\begin{tabular}{|c|c|c|c|c|c|c|c|c|c|}
\hline \multirow{2}{*}{ No } & \multirow{2}{*}{ Guru } & \multicolumn{5}{|c|}{ Indikator/aspek } & \multirow{2}{*}{$\begin{array}{l}\text { Total } \\
\text { skor }\end{array}$} & \multirow{2}{*}{$(\%)$} & \multirow{2}{*}{$\begin{array}{l}\text { Kate- } \\
\text { gori }\end{array}$} \\
\hline & & 1 & 2 & 3 & 4 & 5 & & & \\
\hline 1 & Set. & 3 & 3 & 2 & 3 & 3 & 14 & 56 & $\mathrm{C}$ \\
\hline 2 & D.N & 3 & 2 & 3 & 3 & 3 & 14 & 56 & $\mathrm{C}$ \\
\hline 3 & Ret. & 4 & 4 & 4 & 3 & 3 & 18 & 72 & $\mathrm{~B}$ \\
\hline 4 & Mak. & 4 & 4 & 4 & 3 & 4 & 19 & 76 & $\mathrm{~B}$ \\
\hline 5 & S. B & 4 & 4 & 4 & 4 & 4 & 20 & 80 & B \\
\hline 6 & T.U & 4 & 4 & 4 & 4 & 3 & 19 & 76 & $\mathrm{~B}$ \\
\hline 7 & D.W & 2 & 2 & 2 & 3 & 3 & 12 & 48 & $\mathrm{C}$ \\
\hline 8 & M. A & 3 & 3 & 2 & 2 & 2 & 12 & 48 & $\mathrm{C}$ \\
\hline \multicolumn{7}{|c|}{ Rata-rata } & 16 & 64 & B \\
\hline
\end{tabular}

Dari data tersebut diambil kesimpulan bahwa rata-rata kedisiplinan guru dalam menyusun perencanaan pembelajaran dalam kondisi baik, ada peningkatan dari kondisi awal karena jika dibandingkan dengan kondisi awal, rata-rata total skor pada siklus 1 naik 6 yang tadinya 10 menjadi 16, dari kondisi kurang menjadi baik rentang rendah. 
Tabel 5

Data Kondisi Akhir Siklus 1 Kedisiplinan Melaksanakan Pembelajaran

\begin{tabular}{|c|c|c|c|c|c|c|c|c|c|c|c|c|c|c|c|c|}
\hline \multirow{2}{*}{ No } & \multirow{2}{*}{ Guru } & \multicolumn{12}{|c|}{ Indikator/aspek } & \multirow{2}{*}{$\begin{array}{l}\text { Total } \\
\text { skor }\end{array}$} & \multirow{2}{*}{$(\%)$} & \multirow{2}{*}{$\begin{array}{r}\text { Kate- } \\
\text { gori }\end{array}$} \\
\hline & & 1 & 2 & 3 & 4 & 5 & 6 & 7 & 8 & 9 & 10 & 11 & 12 & & & \\
\hline 1 & Set. & 2 & 3 & 3 & 2 & 2 & 2 & 3 & 3 & 2 & 2 & 2 & 2 & 28 & 46,67 & $\mathrm{C}$ \\
\hline 2 & D.N & 3 & 3 & 3 & 3 & 4 & 3 & 4 & 3 & 4 & 4 & 3 & 3 & 40 & 66,67 & $\mathrm{~B}$ \\
\hline 3 & Ret. & 4 & 4 & 3 & 3 & 3 & 4 & 3 & 3 & 3 & 4 & 4 & 3 & 41 & 68,33 & $\mathrm{~B}$ \\
\hline 4 & Mak. & 4 & 4 & 4 & 4 & 3 & 4 & 3 & 4 & 4 & 3 & 3 & 4 & 44 & 73,33 & $\mathrm{~B}$ \\
\hline 5 & S. B & 4 & 4 & 4 & 4 & 4 & 4 & 4 & 4 & 4 & 4 & 4 & 3 & 47 & 78,33 & B \\
\hline 6 & T.U & 4 & 4 & 4 & 4 & 4 & 4 & 3 & 4 & 4 & 4 & 4 & 4 & 45 & 75 & B \\
\hline 7 & D.W & 3 & 3 & 3 & 3 & 3 & 3 & 3 & 3 & 3 & 3 & 3 & 2 & 35 & 58,33 & $\mathrm{C}$ \\
\hline 8 & M. A & 3 & 3 & 3 & 3 & 3 & 3 & 3 & 3 & 3 & 2 & 3 & 2 & 34 & 56,67 & $\mathrm{C}$ \\
\hline \multicolumn{14}{|c|}{-rata } & 39,25 & 65,42 & B \\
\hline
\end{tabular}

Dari data tersebut diambil kesimpulan bahwa rata-rata kedisiplinan guru dalam melaksanakan pembelajaran dalam kondisi baik, ada peningkatan dari kondisi awal karena jika dibandingkan dengan kondisi awal, rata-rata total skor pada siklus 1 naik 15,375, yang tadinya 23,875 menjadi 39,25 dari kondisi kurang menjadi baik rentang rendah.

Tabel 6

Data Kondisi Akhir Siklus 1 Kedisiplinan Melaksanakan Evaluasi

\begin{tabular}{|c|c|c|c|c|c|c|c|c|c|c|c|c|c|c|c|c|}
\hline \multirow{2}{*}{ No } & \multirow{2}{*}{ Guru } & \multicolumn{12}{|c|}{ Indikator/Aspek } & \multirow{2}{*}{$\begin{array}{l}\text { Total } \\
\text { skor }\end{array}$} & \multirow{2}{*}{$(\%)$} & \multirow{2}{*}{$\begin{array}{l}\text { Kate- } \\
\text { gori }\end{array}$} \\
\hline & & 1 & 2 & 3 & 4 & 5 & 6 & 7 & 8 & 9 & 10 & 11 & 12 & & & \\
\hline 1 & Set. & 3 & 3 & 3 & 3 & 3 & 2 & 3 & 3 & 2 & 3 & 3 & 3 & 34 & 56,67 & $\mathrm{C}$ \\
\hline 2 & D.N & 4 & 3 & 3 & 3 & 3 & 3 & 3 & 3 & 3 & 4 & 3 & 3 & 38 & 63,33 & $\mathrm{~B}$ \\
\hline 3 & Ret. & 3 & 3 & 3 & 3 & 3 & 3 & 4 & 3 & 3 & 3 & 3 & 3 & 37 & 61,67 & $\mathrm{~B}$ \\
\hline 4 & Mak. & 3 & 3 & 3 & 3 & 3 & 3 & 4 & 3 & 3 & 4 & 3 & 3 & 38 & 63,33 & $\mathrm{~B}$ \\
\hline 5 & S. B & 4 & 3 & 4 & 4 & 4 & 5 & 4 & 4 & 4 & 4 & 4 & 4 & 48 & 80 & $\mathrm{~B}$ \\
\hline 6 & T.U & 4 & 4 & 3 & 4 & 4 & 4 & 3 & 3 & 4 & 3 & 3 & 3 & 42 & 70 & $\mathrm{~B}$ \\
\hline 7 & D.W & 2 & 2 & 2 & 2 & 2 & 3 & 2 & 2 & 2 & 2 & 3 & 2 & 26 & 43,33 & $\mathrm{C}$ \\
\hline 8 & M. A & 2 & 2 & 2 & 3 & 2 & 2 & 2 & 2 & 2 & 2 & 2 & 2 & 25 & 41,67 & $\mathrm{C}$ \\
\hline & & & & & & ta-r & & & & & & & & 36 & 60 & $\mathrm{C}$ \\
\hline
\end{tabular}

Dari data tersebut diambil kesimpulan bahwa rata-rata kedisiplinan guru dalam melaksanakan evaluasi dalam kondisi cukup, ada peningkatan dari kondisi awal karena jika dibandingkan dengan kondisi awal, rata-rata total skor pada siklus 1 naik 12,25 yang tadinya 23,75 menjadi 36, dari kondisi kurang menjadi cukup rentang tinggi. 
Upaya Meningkatkan Kedisiplinan Mengajar Guru Melalui Supervisi Akademik dengan

Teknik Individual ..(Kunthi Arifah)

\section{Siklus II}

Tindakan pada siklus II merupakan tindak lanjut dari siklus I. Siklus II dilakukan pada bulan Maret 2015. Pada tahap perencanaan tindakan peneliti menyusun perencanaan kegiatan yang disepakati bersama guru yang akan disupervisi pada siklus II. Adapun langkah-langkah yang ditempuh adalah sebagai berikut : 1) Peneliti memberikan masukan kepada guru, 2) Guru meyusun rencana pembelajaran yang sesuai dengan yang akan dilaksanakan, 3) Guru berdiskusi dengan peneliti untuk menentukan aspek-aspek yang akan diperhatikan untuk memperbaiki penampilan.

Pada tahap pelaksanaan tindakan siklus II ini dilaksanakan dalam 1 pertemuan. Peneliti mengunjungi kelas pada saat KBM dan mencatat kejadiankejadian selama KBM dalam lembar instrumen yang sudah disiapkan. Tindakan pada siklus II menyajikan materi lanjutan dari siklus I.

Adapun hasil dari kegiatan supervisi akademik dengan teknik individual dengan melakukan supervisi kunjungan kelas pada siklus II adalah sebagai berikut :

Tabel 7

Data Kondisi Akhir Siklus II

Kedisiplinan Menyusun Perencanaan Pembelajaran

\begin{tabular}{|c|c|c|c|c|c|c|c|c|c|}
\hline \multirow{2}{*}{ No } & \multirow{2}{*}{ Guru } & \multicolumn{5}{|c|}{ Indikator/Aspek } & \multirow{2}{*}{$\begin{array}{l}\text { Total } \\
\text { skor }\end{array}$} & \multirow[b]{2}{*}{ (\%) } & \multirow{2}{*}{ Kategori } \\
\hline & & 1 & 2 & 3 & 4 & 5 & & & \\
\hline 1 & Set. & 3 & 5 & 4 & 4 & 4 & 20 & 80 & B \\
\hline 2 & D.N & 4 & 5 & 4 & 5 & 4 & 22 & 88 & $\mathrm{AB}$ \\
\hline 3 & Ret. & 4 & 4 & 4 & 4 & 4 & 20 & 80 & $\mathrm{~B}$ \\
\hline 4 & Mak. & 4 & 4 & 4 & 3 & 4 & 19 & 76 & $\mathrm{~B}$ \\
\hline 5 & S. B & 5 & 5 & 5 & 4 & 5 & 24 & 96 & $\mathrm{AB}$ \\
\hline 6 & T.U & 5 & 4 & 4 & 5 & 5 & 23 & 92 & $\mathrm{AB}$ \\
\hline 7 & D.W & 4 & 4 & 3 & 3 & 4 & 18 & 72 & $\mathrm{~B}$ \\
\hline 8 & M. A & 3 & 3 & 2 & 4 & 3 & 15 & 60 & $\mathrm{C}$ \\
\hline & & Rata- & ata & & & & 20,125 & 80,5 & $\mathrm{AB}$ \\
\hline
\end{tabular}

Dari data tersebut diambil kesimpulan bahwa rata-rata kedisiplinan guru dalam menyusun perencanaan pembelajaran setelah siklus II dalam kondisi amat baik rentang rendah, ada peningkatan dari kondisi akhir siklus I karena jika dibandingkan dengan kondisi akhir siklus I, rata-rata total skor pada siklus II naik 4,125 yang tadinya 16 menjadi 20,125, dari kondisi baik rentang rendah menjadi amat baik rentang rendah. 
Tabel 8

Data Kondisi Akhir Siklus II Kedisiplinan Melaksanakan Pembelajaran

\begin{tabular}{|c|c|c|c|c|c|c|c|c|c|c|c|c|c|c|}
\hline \multirow{2}{*}{ No } & \multirow{2}{*}{ Guru } & \multicolumn{10}{|c|}{ Indikator/Aspek } & \multirow{2}{*}{$\begin{array}{l}\text { Total } \\
\text { skor }\end{array}$} & \multirow{2}{*}{$(\%)$} & \multirow{2}{*}{$\begin{array}{l}\text { Kate- } \\
\text { gori }\end{array}$} \\
\hline & & 1 & 2 & 3 & \begin{tabular}{l|l|}
4 & 5
\end{tabular} & \begin{tabular}{|l|l}
6 & 7 \\
\end{tabular} & \begin{tabular}{l|l|l}
7 & 8 \\
\end{tabular} & 9 & 10 & 11 & 12 & & & \\
\hline 1 & Set. & 3 & $3 \mid$ & 3 & \begin{tabular}{l|l|}
4 & 3 \\
\end{tabular} & \begin{tabular}{|l|l}
3 & 3 \\
\end{tabular} & \begin{tabular}{l|l}
3 & 3 \\
\end{tabular} & 4 & 4 & 3 & 3 & 39 & 65 & $\mathrm{~B}$ \\
\hline 2 & D.N & 5 & 5 & 4 & \begin{tabular}{l|l|}
4 & 4 \\
\end{tabular} & \begin{tabular}{c|c}
5 & 2 \\
\end{tabular} & 4 & 4 & 4 & 4 & 4 & 51 & 85 & $\mathrm{AB}$ \\
\hline 3 & Ret. & 4 & 4 & 5 & 4 & \begin{tabular}{l|l}
4 & 2 \\
\end{tabular} & 5 & 3 & 4 & 4 & 4 & 48 & 80 & $\mathrm{~B}$ \\
\hline 4 & Mak. & 5 & 5 & 4 & 4 & \begin{tabular}{c|c}
4 & 2 \\
\end{tabular} & 5 & 4 & 4 & 4 & 4 & 52 & 86,67 & $\mathrm{AB}$ \\
\hline 5 & S. B & 5 & 5 & 5 & 4 & \begin{tabular}{l|l}
4 & 5 \\
\end{tabular} & 4 & 4 & 4 & 5 & 5 & 55 & 91.67 & $\mathrm{AB}$ \\
\hline 6 & T.U & 5 & 5 & 4 & \begin{tabular}{l|l|}
4 & 4 \\
\end{tabular} & \begin{tabular}{l|l}
4 & 5 \\
\end{tabular} & 4 & 4 & 4 & 5 & 4 & 52 & 86,67 & $\mathrm{AB}$ \\
\hline 7 & D.W & 3 & 3 & 3 & \begin{tabular}{|l|l|}
3 & 3 \\
\end{tabular} & \begin{tabular}{|l|l}
3 & 3 \\
\end{tabular} & 3 & 3 & 3 & 2 & 3 & 35 & 58,33 & $\mathrm{C}$ \\
\hline 8 & M. A & 4 & 3 & \begin{tabular}{l|l}
3 \\
\end{tabular} & \begin{tabular}{|l|l|}
3 & 3 \\
\end{tabular} & \begin{tabular}{|l|l}
3 & 3 \\
\end{tabular} & \begin{tabular}{l|l}
3 & 3 \\
\end{tabular} & 3 & 4 & 3 & 3 & 38 & 63,33 & $\mathrm{~B}$ \\
\hline & & & & & Rata- & rata & & & & & & 46,25 & 77,08 & B \\
\hline
\end{tabular}

Dari data tersebut diambil kesimpulan bahwa rata-rata kedisiplinan guru dalam melaksanakan pembelajaran dalam kondisi baik, ada peningkatan dari kondisi akhir siklus I karena jika dibandingkan dengan kondisi akhir siklus I, rata-rata total skor pada siklus II naik 7, yang tadinya 39,25 menjadi 46,25 dari kondisi baik rentang rendah menjadi baik rentang tinggi.

Tabel 9

Data Kondisi Akhir Siklus II

Kedisiplinan Melaksanakan Evaluasi

\begin{tabular}{|c|c|c|c|c|c|c|c|c|c|c|c|c|c|c|c|c|}
\hline \multirow{2}{*}{ No } & \multirow{2}{*}{ Guru } & \multicolumn{12}{|c|}{ Indikator/Aspek } & \multirow{2}{*}{$\begin{array}{l}\text { Total } \\
\text { skor }\end{array}$} & \multirow{2}{*}{$(\%)$} & \multirow{2}{*}{$\begin{array}{c}\text { Kate- } \\
\text { gori }\end{array}$} \\
\hline & & 1 & \begin{tabular}{|l|l|}
2 & \\
\end{tabular} & 3 & \begin{tabular}{|l|}
4 \\
\end{tabular} & 5 & 6 & 7 & 8 & 9 & 10 & 11 & 12 & & & \\
\hline 1 & Set. & 4 & 4 & 4 & 4 & 4 & \begin{tabular}{|l|l}
3 &
\end{tabular} & 4 & 3 & 3 & 4 & 4 & 4 & 45 & 75 & B \\
\hline 2 & D.N & 4 & 3 & 4 & 4 & 4 & \begin{tabular}{l|l}
4 & \\
\end{tabular} & 4 & 4 & 4 & 4 & 4 & 4 & 47 & 78,33 & B \\
\hline 3 & Ret. & 3 & \begin{tabular}{l|l}
4 \\
\end{tabular} & 4 & 3 & 4 & \begin{tabular}{l|l}
3 & \\
\end{tabular} & 4 & 3 & 3 & 4 & 4 & 4 & 43 & 71,67 & $B$ \\
\hline 4 & Mak. & 5 & 5 & 4 & 5 & 5 & \begin{tabular}{l|l}
5 & \\
\end{tabular} & 4 & 4 & 4 & 4 & 4 & 4 & 53 & 88,33 & $\mathrm{AB}$ \\
\hline 5 & S. B & 5 & \begin{tabular}{l|l}
4 \\
\end{tabular} & 5 & 4 & 5 & \begin{tabular}{l|l|}
5 & \\
\end{tabular} & 5 & 5 & 5 & 5 & 5 & 5 & 58 & 96,67 & $\mathrm{AB}$ \\
\hline 6 & T.U & 5 & \begin{tabular}{l|l|}
5 & \\
\end{tabular} & 5 & 5 & 5 & \begin{tabular}{l|l|}
4 & \\
\end{tabular} & 5 & 4 & 4 & 4 & 4 & 4 & 54 & 90 & $\mathrm{AB}$ \\
\hline 7 & D.W & 3 & \begin{tabular}{l|l}
3 \\
\end{tabular} & 4 & 4 & 4 & \begin{tabular}{l|l}
3 \\
\end{tabular} & 3 & 3 & 3 & 3 & 3 & 3 & 39 & 65 & B \\
\hline 8 & M. A & 3 & \begin{tabular}{l|l}
3 & \\
\end{tabular} & 2 & 3 & 3 & \begin{tabular}{l|l|}
3 & \\
\end{tabular} & 3 & 3 & 3 & 3 & 3 & 3 & 35 & 58,33 & $\mathrm{C}$ \\
\hline & & & & & & ta-r & & & & & & & & 46,75 & 77.92 & B \\
\hline
\end{tabular}

Dari tabel tersebut diambil kesimpulan bahwa rata-rata kedisiplinan guru dalam melaksanakan evaluasi dalam kondisi baik, ada peningkatan dari kondisi akhir siklus I karena jika dibandingkan dengan kondisi akhir siklus I, rata-rata total skor pada siklus II naik 10,75 yang tadinya 36 menjadi 46,75, dari kondisi cukup rentang tinggi menjadi baik rentang tinggi. 
Upaya Meningkatkan Kedisiplinan Mengajar Guru Melalui Supervisi Akademik dengan

Teknik Individual ..(Kunthi Arifah)

\section{Pembahasan Hasil Penelitian}

Hasil penelitian tindakan sekolah yang dilakukan melalui supervisi akademik dengan teknik individual memiliki dampak positif dalam meningkatkan kedisiplinan mengajar guru. Dengan dilakukan revisi setiap siklus didapat hasil yang lebih baik dari siklus sebelumnya. Adapun peningkatan/perbandingan hasil supervisi akademik teknik individual terhadap kedisiplinan mengajar guru dari siklus I dan siklus II adalah sebagai berikut :

\section{Tabel 10}

Perbandingan Kedisiplinan Menyusun Perencanaan Pembelajaran

Pada Kondisi Awal, Akhir Siklus I dengan Setelah Siklus II

\begin{tabular}{|l|l|c|c|c|}
\hline No & \multicolumn{1}{|c|}{ Keterangan } & $\begin{array}{c}\text { Kondisi } \\
\text { Awal }\end{array}$ & Siklus I & Siklus II \\
\hline 1 & Rata-rata Skor & 10 & 16 & 20,125 \\
\hline 2 & Kategori & Kurang & Baik & Amat baik \\
\hline
\end{tabular}

Tabel 11

Perbandingan Kedisiplinan Melaksanakan Pembelajaran

Pada Kondisi Awal, Akhir Siklus I dengan Setelah Siklus II

\begin{tabular}{|l|l|c|c|c|}
\hline No & \multicolumn{1}{|c|}{ Keterangan } & $\begin{array}{c}\text { Kondisi } \\
\text { Awal }\end{array}$ & Siklus I & Siklus II \\
\hline 1 & Rata-rata Skor & 23,87 & 39,25 & 46,25 \\
\hline 2 & Kategori & Kurang & Baik & Baik \\
\hline
\end{tabular}

Tabel 12

Perbandingan Kedisiplinan Melaksanakan Evaluasi

Pada Kondisi Awal, Akhir Siklus I dengan Setelah Siklus II

\begin{tabular}{|l|l|c|c|c|}
\hline No & Keterangan & $\begin{array}{c}\text { Kondisi } \\
\text { Awal }\end{array}$ & Siklus I & Siklus II \\
\hline 1 & Rata-rata Skor & 23,75 & 36 & 46,75 \\
\hline 2 & Kategori & Kurang & Cukup & Baik \\
\hline
\end{tabular}

Dari Tabel 10, Tabel 11 dan Tabel 12 ini bisa dilihat bahwa rata-rata skor dari kondisi awal, siklus I dan siklus II selalu mengalami peningkatan. Dari sini dapat dijelaskan bahwa melalui supervisi akademik dengan teknik individual dapat meningkatkan kedisiplinan mengajar guru yang meliputi kedisiplinan dalam menyusun perencanaan pembelajaran, kedisiplinan dalam melaksanakan pembelajaran, dan kedisiplinan dalam melaksanakan evaluasi. 


\section{PENUTUP}

\section{Simpulan}

Dengan melaksanakan supervisi akademik teknik individual dapat meningkatkan kedisiplinan mengajar guru SD Negeri Candirejo 01 yang meliputi kedisiplinan dalam menyusun perencanaan pembelajaran, kedisiplinan dalam melaksanakan pembelajaran, dan kedisiplinan dalam melaksanakan evaluasi.

\section{Saran}

Berdasarkan hasil yang diperoleh dalam penelitian tindakan sekolah ini peneliti mengajukan saran-saran sebagai berikut (1) Hendaknya para guru dapat menyusun perangakat pembelajaran secara mandiri atau bersama KKG atau setidaknya mengadaptasikan yang sudah dimiliki dengan keadaan sekolah, (2) Hendaknya para guru memfasilitasi pembelajaran dengan model yang variatif, (3) Hendaknya para guru menjaga kualitas pembelajaran tidak hanya pada saat dilaksanakan supervisi oleh kepala sekolah, atau pengawas saja, tetapi tetap menjaga kualitas kapanpun dia mengajar, (4) Hendaknya kepala sekolah secara berkala melakukan supervisi untuk mengontrol kegiatan pembelajaran.

\section{DAFTAR PUSTAKA}

Bafadal, Ibrahim, 2006. Kumpulan Materi Peningkatan Ketrampilan Manajerial Kepala Sekolah, Jakarta: Direktorat Pendidikan Nasional

Damayanti, dkk. 2002. Belajar dan Pembelajaran. Jakarta. PT Rineka Cipta.

Glickman, C.D., Gordon, S.P., and Ross-Gordon, J.M. 2007. Supervision and Instructional Leadership A Development Approach. Seventh Edition. Boston: Pearson.

Gwynn, J.M. 1961. Theory and Practice of Supervision.New York: Dodd, Mead \& Company.

Haryadi, 2005. Faktor-faktor yang Mempengaruhi Kinerja Dosen dan Hasil Belajar Mahasiswa Universitas Jendral Soedirman Porwokerto, Disertasi, Bandung: Program Pascasarjana Universitas Pendidikan Indonesia.

Hasibuan, M. 2000. Manajemen Sumber Daya Manusia. Jakarta: Bumi Aksara.

Mulyasa, E, 2004. Menjadi Kepala Sekolah Profesional, Bandung: PT Remaja Rosdakarya

Sergiovanni, T.J. 1982. Supervision of Teaching. Alexandria: Association for Supervision and Curriculum Development.

Sudiyono, A., 2001. Pengantar Evaluasi Pendidikan, Jakarta: Raja Grafindo Persada 
Upaya Meningkatkan Kedisiplinan Mengajar Guru Melalui Supervisi Akademik dengan

Teknik Individual ..(Kunthi Arifah)

Sugiyono. 2004. Pengaruh Pembinaan Kepala Sekolah, Motivasi Kerja dan Pengalaman Diklat Terhadap Kinerja Guru Dalam Pembelajaran Bahasa Madura di SD Negeri Kecamatan Bangkalan Kabupaten Bangkalan Madura. Jurnal Penelitian Pendidikan No. 7 Tahun VI

Tu'u, Tulus. 2004. Peran Disiplin pada Perilaku dan Prestasi Siswa. Jakarta: Grasindo

Undang-undang Nomor 20 Tahun 2003 Tentang Sistem Pendidikan Nasional. Bandung: Citra Umbara

Undang-undang Republik Indonesia Nomor 14 Tahun 2005 Tentang Guru dan Dosen. Semarang: Duta Nusinda

Wiles, J. Dan J. Bondi. 1986. Supervision: A Guide to Practice. Second Edition. Columbus: Charles E. Merrill Publishing Company. 